\title{
Avoiding Complications in the Hospitalized Patient: The Case for Tight Glycemic Control
}

Franklin Michota, мо ${ }^{1}$

Susan S. Braithwaite, $\mathrm{MD}^{2}$

${ }^{1}$ Section of Hospital Medicine, Department of General Internal Medicine, Cleveland Clinic, Cleveland, Ohio

${ }^{2}$ University of North Carolina, Chapel Hill, North Carolina
$\mathbf{H}^{2}$ yperglycemia is common in the hospital among patients with diabetes and those without. The exact overall prevalence of diabetes in the hospital is unknown; however, in 2000, $12.4 \%$ of U.S. hospital discharges listed diabetes as a diagnosis. Among cardiac surgery patients, the prevalence of diabetes is as high as $29 \% .^{2}$ Another study reported a $26 \%$ prevalence of diabetes in a community teaching hospital, with an additional $12 \%$ of patients having unrecognized diabetes or hospital-related hyperglycemia. ${ }^{3}$ Levetan et al. found laboratory-documented hyperglycemia in $13 \%$ of 1034 consecutively hospitalized patients. ${ }^{4}$ A subsequent chart review found that more than one-third of patients with hyperglycemia identified by laboratory testing remained unrecognized as having diabetes documented in the discharge summary, although diabetes or hyperglycemia was noted in the progress notes. In a retrospective chart review study, Umpierrez et al. similarly found $38 \%$ of 1886 consecutively hospitalized patients who had glucose measurements on admission were hyperglycemic. ${ }^{3}$ One-third of these patients were not previously known to have diabetes, and compared to patients with diagnosed diabetes, they were more likely to require admission to the intensive care unit, had longer hospital stays, and were less likely to be discharged straight home.

Until recently, most clinicians viewed tight glucose control in the hospitalized patient as an intervention with little immediate benefit and significant potential for harm. The goal was simply to prevent excessive hyperglycemia and avoid ketoacidosis or significant fluid derangements while minimizing the risk for hypoglycemia. Today, a growing body of evidence suggests a close correlation between tight glucose control and improved clinical outcomes. Among those who have had a myocardial infarction and those in the surgical intensive care unit, it is known that intensive glycemic control reduces mortality. ${ }^{5,6}$ Maintaining normoglycemia in patients in the surgical intensive care unit through intravenous insulin infusion also reduces the incidence of comorbidities such as transfusion requirements, renal failure, sepsis, and neuropathy and reduces the duration of ventilator dependence. ${ }^{6}$ Although trials using glucose-insulin-potassium infusions (GIK), when conducted such that lowering of blood glucose occurred, have shown benefit in the settings of myocardial infarction ${ }^{5,7}$ and cardiac surgery, ${ }^{8}$ not all studies of GIK therapy have yielded positive results. The negative results of the CREATE-ECLA study suggest that GIK therapy per se is not beneficial unless it reduces blood glucose. ${ }^{9}$ An abundance of additional observational data and comparisons with historical control data suggest that favor- 
able outcomes might be causally dependent on euglycemia. The outcomes studied include hospital or critical care unit mortality and nosocomial infection, ${ }^{10-14}$ specifically outcomes of strokes, ${ }^{15-22}$ trauma, ${ }^{23-25}$ renal transplantation, ${ }^{26-28}$ myocardial infarction, ${ }^{29-36}$ endocarditis, ${ }^{37}$ acute lymphocytic leukemia, ${ }^{38}$ community-acquired pneumonia, ${ }^{39}$ infectious complications in the hospital, ${ }^{40-46}$ and cardiac surgery, ${ }^{9,44,45,47-51}$ as well as length of stay and costs. ${ }^{11,25,51-56}$

It is important for each hospital to consider the methodology used for blood glucose measurement, realizing that measurements in the Leuven Belgium studies were performed on arterial whole blood using a blood gas analyzer. With recognition that the normal range for blood glucose is method dependent, the data presented above form the basis for the recommended glycemic targets for hospitalized patients:

Target range blood glucose (AACE et al., 2004)

- Preprandial: $<110 \mathrm{mg} / \mathrm{dL}$

- Peak postprandial: $<180 \mathrm{mg} / \mathrm{dL}$

- Critically ill surgical patients: $80-110 \mathrm{mg} / \mathrm{dL}$

Target range blood glucose (ADA, 2006)

- Critically ill:

Blood glucose as close to $110 \mathrm{mg} / \mathrm{dL}$ as possible and generally $<180 \mathrm{mg} / \mathrm{dL}$.

These patients generally will require IV insulin.

- Noncritically ill:

Premeal blood glucose as close to $90-130 \mathrm{mg} / \mathrm{dL}$ as possible (midpoint $110 \mathrm{mg} / \mathrm{dL}$ ).

Postprandial blood glucose $<180 \mathrm{mg} / \mathrm{dL}$.

This supplement, "Avoiding Complications in the Hospitalized Patient: The Case for Tight Glycemic Control," reviews several aspects of hyperglycemia in the hospital setting. Evidence that supports more intensive glucose control is reviewed, along with a "realworld" success story that demonstrates how to apply the new glycemic targets in a multidisciplinary performance improvement project. In addition, the standard insulin "sliding scale" is examined in terms of efficacy, safety, and potential for meeting the new recommended glycemic targets.

Address for correspondence and reprint requests: Franklin Michota, Head, Section of Hospital Medicine, S70/Department of General Internal Medicine, Cleveland Clinic, 9500 Euclid Avenue, Cleveland, OH 44195; Fax: (216) 4456240; E-mail: michotf@ccf.org

Received 28 July 2006; accepted 12 December 2006.

\section{REFERENCES}

1. Tierney E: Data from the national hospital discharge survey database 2000. Centers for Disease Control and Prevention, Division of Diabetes translation, Atlanta, GA, 2003.

2. Moghissi E: Hospital management of diabetes: beyond the sliding scale. Clev Clin J Med. 2004;71:801-808.

3. Umpierrez GE, Isaacs SD, Bazargan N, You X, Thaler LM, Kitabchi AE. Hyperglycemia: an independent marker of inhospital mortality in patients with undiagnosed diabetes. J Clin Endocrinol Metab. 2002;87:978-982.

4. Levetan CS, Passaro M, Jablonski K, Kass M, Ratner RE: Unrecognized diabetes among hospitalized patients. Diabetes Care. 1998;21:246-249.

5. Malmberg K, for the DIGAMI study group. Prospective randomised study of intensive insulin treatment on long term survival after acute myocardial infarction in patients with diabetes mellitus. BMJ. 1997;314:1512-1515.

6. Van den Berghe G, Wouters P, Weekers F, et al. Intensive insulin therapy in critically ill patients. N Engl J Med. 2001; 345:1359-1367.

7. Malmberg K, Rydén L, Efendic S, et al. Randomized trial of insulin-glucose infusion followed by subcutaneous insulin treatment in diabetic patients with acute myocardial infarction (DIGAMI study): effects on mortality at 1 year. J Am Coll Cardiol. 1995;26:57-65.

8. Lazar HL, Chipkin SR, Fitzgerald CA, Bao Y, Cabral H, Apstein CS. Tight glycemic control in diabetic coronary artery bypass graft patients improves perioperative outcomes and decreases recurrent ischemic events. Circulation. 2004;109: 1497-1502.

9. CREATE-ECLA Trial Group Investigators. Effect of glucoseinsulin-potassium infusion on mortality in patients with acute st-segment elevation myocardial infarction: the CREATE-ECLA randomized controlled trial. JAMA. 2005;293:437-446.

10. Van den Berghe G, Wilmer A, Hermans G, et al. Intensive insulin therapy in the medical ICU. N Engl J Med. 2006;354: 449-461.

11. Grey NJ, Perdrizet GA. Reduction of nosocomial infections in the surgical intensive-care unit by strict glycemic control. Endocr Pract. 2004;10(suppl 2):46-52.

12. Furnary AP, Gao G, Grunkemeier GL, et al. Continuous insulin infusion reduces mortality in patients with diabetes undergoing coronary artery bypass grafting. J Thorac Cardiovasc Surg. 2003;125:1007-1021.

13. Stagnaro-Green A, Barton MK, Linekin PL, Corkery E, deBeer K, Roman SH. Mortalilty in hospitalized patients with hypoglycemia and severe hyperglycemia. Mt Sinai J Med. 1995;62:422-426.

14. Umpierrez GE, Isaacs SD, Bazargan N, You X, Thaler LM, Kitabchi AE. Hyperglycemia: an independent marker of inhospital mortality in patients with undiagnosed diabetes. J Clin Endocrinol Metab. 2002;87:978-982.

15. Finney SJ, Zekveld C, Elia A, Evans TW. Glucose control and mortality in critically ill patients. JAMA. 2003;290: 2041-2047.

16. Krinsley JS. Effect of an intensive glucose management protocol on the mortality of critically ill adult patients. Mayo Clin Proc. 2004:79:992-1000.

17. Pittas AG, Siegel RD, Lau J. Insulin therapy for critically ill hospitalized patients: a meta-analysis of randomized controlled trials. Arch Intern Med. 2004;164:2005-2011. 
18. Baird TA, Parsons MW, Phanh T, et al. Persistent poststroke hyperglycemia is independently associated with infarct expansion and worse clinical outcome. Stroke. 2003;34:22082214.

19. Capes S, Hunt D, Malmberg K, Pathak P, Gerstein H. Stress hyperglycemia and prognosis of stroke in nodiabetic and diabetic patients: a systematic overview. Stroke. 2001;32: 2426-2432.

20. Bruno A, Levine SR, Frankel MR, et al. Admission glucose level and clinical outcomes in the NINDS rt-PA Stroke Trial. Neurology. 2002;59:669-674.

21. Levetan CS. Effect of hyperglycemia on stroke outcomes. Endocr Pract. 2004;10(suppl 2):34-39.

22. Leigh R, Zaidat OO, Suri MF, et al. Predictors of hyperacute clinical worsening in ischemic stroke patients receiving thrombolytic therapy. Stroke. 2004;35:1903-1907.

23. Lindsberg PJ, Roine RO. Hyperglycemia in acute stroke. Stroke. 2004;35:363-364.

24. Gentile NT, Seftchick MW, Huynh T, Kruus LK, Gaughan J. Decreased mortality by normalizing blood glucose after acute ischemic stroke. Acad Emerg Med. 2006;13:174-180.

25. Gentile NT, Seftchick M, Martin R. Blood glucose control after acute stroke: a retrospective study. Acad Emerg Med. 2003;10:432.

26. Laird AM, Miller PR, Kilgo PD, Meredith JW, Chang MC. Relationship of early hyperglycemia to mortality in trauma patients. J Trauma. 2004;56:1058-1062.

27. Sung J, Bochicchio GV, Joshi M, Bochicchio K, Tracy K, Scalea TM. Admission hyperglycemia is predictive of outcome in critically ill trauma patients. J Trauma. 2005;59:8083.

28. Williams LS, Rotich J, Qi R, et al. Effects of admission hyperglycemia on mortality and costs in acute ischemic stroke. Neurology. 2002;59(1):67-71.

29. Thomas M, Mathew T, Russ G, Rao M, Moran J. Early perioperative glycaemic control and allograft rejection in patients with diabetes mellitus: a pilot study. Transplantation. 2001;72:1321-1324.

30. Thomas MC, Moran J, Mathew TH, Russ GR, Mohan Rao M. Early peri-operative hyperglycaemia and renal allograft rejection in patients without diabetes. BMC Nephrol. 2000;1:1.

31. Melin J, Hellberg L, Larsson E, Zezina L, Fellstrom B. Protective effect of insulin on ischemic renal injury in diabetes mellitus. Kidney Int. 2002;61:1383-1392.

32. Bolk J, van der Ploeg T, Cornel JH, Arnold AE, Sepers J, Umans VA. Impaired glucose metabolism predicts mortality after a myocardial infarction. Int J Cardiol. 2001;79(2-3):207214.

33. Capes S, Hunt D, Malmberg K, Gerstein H. Stress hyperglycaemia and increased risk of death after myocardial infarction in patients with and without diabetes: a systematic overview. Lancet. 2000;355:773-778.

34. Foo K, Cooper J, Deaner A, et al. A single serum glucose measurement predicts adverse outcomes across the whole range of acute coronary syndromes. Heart. 2003; 89:512-516.

35. Schnell O, Schafer O, Kleybrink S, Doering W, Standl E, Otter W. Intensification of therapeutic approaches reduces mortality in diabetic patients with acute myocardial infarction: the Munich registry. Diabetes Care. 2004;27:455-460.
36. Stranders I, Diamant M, van Gelder RE, et al. Admission blood glucose level as risk indicator of death after myocardial infarction in patients with and without diabetes mellitus. Arch Intern Med. 2004;164:982-988.

37. Malmberg K, Norhammar A, Wedel H, Ryden L. Glycometabolic state at admission: important risk marker of mortality in conventionally treated patients with diabetes mellitus and acute myocardial infarction: long-term results from the diabetes and insulin-glucose infusion in acute myocardial infarction (DIGAMI) study. Circulation. 1999;99:2626-2632.

38. Meier JJ, Deifuss S, Klamann A, Launhardt V, Schmiegel WH, Nauck MA. Plasma glucose at hospital admission and previous metabolic control determine myocardial infarct size and survival in patients with and without type 2 diabetes: the Langendreer Myocardial Infarction and Blood Glucose in Diabetic Patients Assessment (LAMBDA). Diabetes Care. 2005;28:2551-2553.

39. Kosiborod M, Rathore SS, Inzucchi SE, et al. Admission glucose and mortality in elderly patients hospitalized with acute myocardial infarction: implications for patients with and without recognized diabetes. Circulation. 2005;111: 3078-3086.

40. Chu VH, Cabell CH, Benjamin DK Jr, et al. Early predictors of in-hospital death in infective endocarditis. Circulation. 2004;109:1745-1749.

41. Weiser M. Relation between the duration of remission and hyperglycemia in induction chemotherapy for acute lymphocytic leukemia. Cancer. 2004;100:1179-1185.

42. Falguera M, Pifarre R, Martin A, Sheikh A, Moreno A. Etiology and outcome of community-acquired pneumonia in patients with diabetes mellitus. Chest. 2005;128:3233-3239.

43. Golden SH, Peart-Vigilance C, Kao WHL, Brancati F. Perioperative glycemic control and the risk of infectious complications in a cohort of adults with diabetes. Diabetes Care. 1999;22:1408-1414.

44. Pomposelli JJ, Baxter JK, Babineau TJ, et al. Early postoperative glucose control predicts nosocomial infection rate in diabetic patients. J Parenter Enteral Nutr. 1998;22(2): 77-81.

45. Latham R, Lancaster AD, Covington JF, Pirolo JS, Thomas CS. The association of diabetes and glucose control with surgical-site infections among cardiothoracic surgery patients. Infect Control Hosp Epidemiol. 2001;22:607-612.

46. Vriesendorp TM, Morelis QJ, DeVries JH, Legemate DA, Hoekstra JBL. Early post-operative glucose levels are an independent risk factor for infection after peripheral vascular surgery. A retrospective study. Eur J Vasc Endovasc Surg. 2004;5:520-525.

47. Zerr KJ, Furnary AP, Grunkemeier GL. Glucose control lowers the risk of wound infection in diabetics after open heart operations. Ann Thorac Surg. 1997;63:356-61.

48. Furnary AP, Zerr KJ, Grunkemeier GL, Starr A. Continuous intravenous insulin infusion reduces the incidence of deep sternal wound infection in diabetic patients after cardiac surgical procedures. Ann Thorac Surg. 1999;67: 352-362.

49. Najarian J, Swavely D, Wilson E, et al. Improving outcomes for diabetic patients undergoing vascular surgery. Diabetes Spectr. 2005;18(1):53-60. 
50. Szabo Z, Hakanson E, Svedjeholm R. Early postoperative outcome and medium-term survival in 540 diabetic and 2239 nondiabetic patients undergoing coronary artery bypass grafting. Ann Thorac Surg. 2002;74: 712-719.

51. McAlister FA, Man J, Bistritz L, Amad H, Tandon P. Diabetes and coronary artery bypass surgery: an examination of perioperative glycemic control and outcomes. Diabetes Care. 2003;26:1518-1524.

52. Furnary AP, Wu Y, Bookin SO. Effect of hyperglycemia and continuous intravenous insulin infusions on outcomes of cardiac surgical procedures: the Portland diabetic project. Endocr Pract. 2004;10(suppl 2):21-33.
53. Lazar HL, Chipkin S, Philippides G, Bao Y, Apstein C. Glucose-insulin-potassium solutions improve outcomes in diabetics who have coronary artery operations. Ann Thorac Surg. 2000;70:145-150.

54. Gandhi GY, Nuttall GA, Abel MD, et al. Intraoperative hyperglycemia and perioperative outcomes in cardiac surgery patients. Mayo Clin Proc. 2005;80:862-866.

55. Furnary AP, Chaugle H, Zerr K, Grunkemeier G. Postoperative hyperglycemia prolongs length of stay in diabetic CABG patients. Circulation. II 2000;102(II):556 (abstract).

56. Ahmann A. Reduction of hospital costs and length of stay by good control of blood glucose levels. Endocr Pract. 2004; 10(suppl 2):53-56. 